\title{
PHYSIOLOGICAL RACES OF RICE BLAST PATHOGEN AND HOST RESISTANT GENES UNDER EGYPTIAN CONDITIONS Shabana, Y. M. ${ }^{1}$; S. M. El-Wahsh ${ }^{2}$; A. F. Abdelkhalik ${ }^{3}$; S. A. Fayzalla $^{1}$ and A. A. Hassan ${ }^{2}$ \\ ${ }^{1}$ Plant Pathol. Dept. Fac. of Agric., Mansoura Univ., Egypt. \\ ${ }^{2}$ Rice Pathol. Dept., Plant Pathol. Res. Inst., Agric. Res. Center, Egypt. \\ ${ }^{3}$ Rice Dept., Field Crops Res. Inst., Agric. Res. Center, Egypt.
}

\begin{abstract}
Experiments were carried out at Rice Research and Training Center during 2009 to 2012 growing seasons. This study aimed at evaluation of some commercial Egyptian rice cultivars and some promising lines against blast disease, identification of effective rice blast resistant genes, and distribution of physiological races and common races of Pyricularia grisea. One hundred and thirty two of $P$. grisea isolates were collected from rice-cultivating governorates in Egypt, namely Kafr ELSheikh (36 isolates), Gharbia (48 isolates), Dakahlia (18 isolates), Sharkia (12 isolates), Damietta (6 isolates) and Beheira (12 isolates). IH race group was the most common race $(47.69 \%)$, followed by IC $(26.58 \%)$ and IF $(12.15 \%)$ groups, While IG, ID and IE $(6.06,6.04$ and $1.49 \%$, respectively) were the minor race groups during this study period. The promising line GZ 9057-6-1-3-2 revealed the highest level of resistance against most isolates tested (98.48\%) followed by Giza 178 and GZ 95232-1-1-1 (96.22\% for each). On the other hand, the susceptible rice cultivars, Sakha 101 and Sakha104, were infected with the most tested isolates $(25.76$ and $61.36 \%$ resistance, respectively). Pi-z- ${ }^{5}$ gene found in IRBLz5-CA and IRBLz5-CA (R) lines scored the highest effective gene of blast resistance $(97.76$ and $95.50 \%$, respectively). This gene was followed by pita- $^{2}$ gene, found in the monogenic line IRBLta2-Re (91.70\%). On the other hand, Pia gene found in IRBLa-A and IRBLa-C lines was the lowest effective resistant gene with zero efficacy against the tested isolates. The highest percentage of race groups from the total identified isolates were obtained from Gharbia and Kafr El-Sheikh governorates (36.53 and 27.27\%, respectively). On other hand, Damietta governorate had the lowest percentage of race groups (4.56\% from the total identified races).
\end{abstract}

Keywords: Rice, blast Pyricularia grisea, resistance gene, physiological races, monogenic lines

\section{INTRODUCTION}

Blast disease, caused by Pyricularia grisea (Cooke) Sacc. teleomorph, Magnaporthe grisea (Hebert) Barr. is one of the most important diseases of rice worldwide (Zeigler et al., 1994) and it is highly variable (Couch and Kohn, 2002). Its frequent appearance during all stages of plant growth greatly reduces yield and grain quality. Using the resistant varieties is the most practical and economical approach to blast control. However, effective and durable use of blast resistance has been limited due to a breakdown of blast resistance genes, with an increasing proportion of blast races virulent against this resistance (Koizumi, 2007). The dynamic interaction between host resistance and fungus virulence in the rice blast pathosystem can be explained by the gene-for-gene theory: that is, for every resistance gene in 


\section{Shabana, Y. M. et al.}

the host, there is a corresponding avirulence gene in the pathogen (Flor, 1971; Silue et al., 1992). Based on the gene-for-gene theory, differential varieties (DVs), which can distinguish pathotypes (races) by their differential reactions to each pathogen strain, have been developed to monitor the blast pathogen population structure and predict the emergence of new blast races. The first DVs for rice blast were developed in the 1960s as international differential varieties (Atkins et al., 1967). Since then, DVs have been developed in several countries based on local pathogen populations. A set of monogenic lines or near-isogenic lines (NILs) with single genes for blast resistance is useful as differential varieties and as a gene source in rice breeding programs. However, the development of monogenic lines is timeconsuming and laborious, and has been limited to a small number of genes (Mackill et al., 1985). The set of monogenic lines (MLs) contained 24 resistance genes in the genetic background of Lijiangxintuanheigu (LTH). In more than 30 countries, these MLs have been used as DVs because of their ability to effectively differentiate between races of the blast fungus and also as gene sources for resistance in breeding programs. However, many of the MLs showed significant differences from LTH for several agronomic traits (Tsunematsu et al., 2000; Fukuta et al., 2004). Eizenga et al. (2006) evaluated 91 entries in greenhouse including five Egyptian rice entries; Egyptian yasmine, GZ 1368-5-4, GZ 5578-2-1-2, GZ 5594-23-1-2 and GZ 5830-48-2-2 (sister line of Sakha 103), to determine resistance genes Pita and Pib. Both Pita and Pib gene were identified in 37 out of 91 evaluated entries. International differential varieties set, including eight rice varieties i.e. Ramind str 3, Zenith, Np125, Usen, Duler, Kanto5l, She-tiao-tsao(s) and Caloro were used to determine blast race group (Atkins et al., 1967). In Egypt, many investigators identified the physiological races of $P$. oryzae according to the international system (EL-Kazzaz, 1973; Abd- El-Hak, 1981; Sehly et al., 1993; Gabr, 2004 and Sehly et al., 2008). Sehly et al. (2008) identified more than 200 blast isolates collected from Egyptian rice-cultivating governorates from 1994 to 2006, on the international differential varieties under artificial inoculation in the greenhouse conditions. They found that from 1994 to 1996, IC was the most common race group (32.5\%) followed by IB, ID and IG race groups, representing 15.0, 15.0 and $12.5 \%$, respectively, while IA group race was absent. During the second period (1997-2000), IH and IG groups were the common races representing 29.6 and $25.8 \%$, respectively, while the rest groups ranged from 1.1 to $16.3 \%$. During 2001 2004, the IG-1 was the most common race representing $50 \%$ and it was specific on Sakha 101. In the last period (2005 and 2006 seasons), IG group was still the most common race (40\%) followed by IB and ID groups representing $20 \%$ for each. Arafa (2012) collected 144 isolates of $P$. grisea from different rice cultivars and weeds, in rice-planting governorates in Egypt. These isolates were identified on international differential varieties and classified into nine race groups, i.e. IA $(0.69 \%)$, IB $(8.33 \%)$, IC $(10.42 \%)$, ID (31.94\%), IE (0.69\%), IF (2.78\%), IG (15.97\%), IH (22.92\%) and II (6.25\%).

The present study aimed at evaluation of some commercial Egyptian rice entries against blast disease, identification of effective rice blast resistant genes, and distribution of physiological races and common races of $P$. grisea. 


\section{MATERIALS AND METHODS}

\section{1- Blast sample collection:}

Rice blast samples were collected from rice-growing governorates; Kafr EL-Sheikh, Gharbia, Sharkia, Dakahlia, Damietta, and Beheira during 2009 and 2010 growing seasons.

\section{2-Isolation of rice blast fungus:}

Typical blast lesions on leaves and panicles from infected rice samples collected from different governorates in Egypt were cut into $1-2 \mathrm{~cm}$ pieces, surface sterilized by immersing into $0.5 \%$ sodium hypochlorite solution for two minutes, rinsed twice with sterilized distilled water, and then placed onto sterilized filter paper in 9-cm-diam. Petri dishes. The plates were incubated at $25^{\circ} \mathrm{C}$ for $24 \mathrm{hr}$ under continuous fluorescent light. Single conidium isolates were generated by streaking conidia from sporulating lesions on $20 \%$ water agar (WA) for $24 \mathrm{hr}$. The germinating single conidium was picked and transferred onto water agar for another $24 \mathrm{hr}$. The tip of single hyphae was cut and grown on banana dextrose agar medium $(200 \mathrm{~g}$ banana $+15 \mathrm{~g}$ glucose $+20 \mathrm{~g}$ agar $/ 1000 \mathrm{ml}$ water) on a disc of sterile filter paper. When the filter papers were completely occupied by the fungal growth, the paper discs were individually transferred into sterilized petri dishes. About one week later, the dried filter papers having the fungus isolates were cut into small pieces. Pieces obtained from each isolate were altogether introduced into a sterilized plastic vial and kept at $-20^{\circ} \mathrm{C}$ for long-term storage according to the technique of (Mekwatanakarn et al., 1999).

\section{3- Spore production:}

For spore production, isolates were individually grown on banana dextrose agar medium under florescent light for 10 days at $28^{\circ} \mathrm{C}$. The spores were harvested at a density of at least 25 spores/microscopic field, examined by $10 x$ objective.

4- Pathogenicity test and identification of pathogen physiological races:

Pathogenicity tests and race identification studies were carried out for the obtained fungal isolates under greenhouse condition with artificial infection. Eight international differential varieties (I.D.V.) i.e., Raminad Str.3, Zenith, NP-125, Usen, Dular, Kanto, Cl 8970s, and Caloro (Atkins et al., 1967) were used to identify blast physiological races. Ten commercial rice cultivars as, Giza 177, Giza 178, Hybrid 1, Giza 182, Sakha 101, Sakha 102, Sakha 103, Sakha 104, Sakha 105 and Sakha 106 In addition, Four promising lines GZ 9057-6-1-3-2, GZ 9523-2-1-1-1, GZ 9461-4-2-1-2 and GZ 6296-12-1-2-1-1, were used to evaluate its resistance level, as well as thirty two monogenic lines of genetic background (obtained from International Rice Research Institute (IRRI)), Philippines, as shown in Table (1), were used to determine effective resistant blast genes. All tested entries were seeded in plastic trays $(30 \times 20 \times 15 \mathrm{~cm}$.). Each tray comprised 10 rows representing eight international differential varieties and two susceptible rice checks (Sakha 101 and Sakha 104). The trays were kept in the greenhouse at 25$30^{\circ} \mathrm{C}$, and fertilized with Urea $46.5 \% \mathrm{~N}(5 \mathrm{~g} /$ tray). Seedlings were ready for inoculation at 3-4-leaf stage, (about 3-4 weeks after sowing), were inoculated 
by spraying with spore suspension. (100 ml) adjusted to $5 \times 10^{4}$ spores $/ \mathrm{ml}$. Gelatin was added to the spore suspension at a concentration of $2.5 \mathrm{~g} / \mathrm{L}$ (Bastiaans, 1993) to enhance the adhesion of spores on leaf surfaces. Each isolate was sprayed using electrical spray gun. The inoculated seedlings were held in a moist chamber with at least $90 \%$ R.H. and $25-28^{\circ} \mathrm{C}$ for $24 \mathrm{hr}$. and then moved to the greenhouse conditions. Seven days after inoculation under greenhouse conditions, blast reaction, as the typical blast lesions was scored, according to the standard evaluation system using 0-9 scale (IRRI, 1996).

Table (1): List of monogenic lines set used as differential varieties.

\begin{tabular}{|c|c|c|c|c|c|}
\hline No. & line & Target gene & No. & Line & Target gene \\
\hline 1 & IRBLa-A & Pia & 17 & IRBLsh-B & Pish \\
\hline 2 & IRBLa-C & Pia & 18 & IRBL1-CL & Pi1 \\
\hline 3 & IRBLi-F5 & Pii & 19 & IRBL3-CP4 & Pi3 \\
\hline 4 & IRBLks-F5 & Pik- $^{s}$ & 20 & IRBL5-M & $\operatorname{Pi5}(\mathrm{t})$ \\
\hline 5 & IRBLks-F5 & Pik-s & 21 & IRBL7-M & $P i 7(\mathrm{t})$ \\
\hline 6 & IRBLk-ka & Pik & 22 & IRBL9-W & Pi9 \\
\hline 7 & IRBLkp-K60 & Pik $^{p}$ & 23 & IRBL12-M & Pi12 (t) \\
\hline 8 & IRBLkh-K3 & Pik- $^{h}($ Pi54) & 24 & IRBL19-A & Pi19 \\
\hline 9 & IRBLz-Fu & Piz & 25 & IRBLkm-Ts & Pik- ${ }^{m}$ \\
\hline 10 & IRBLz5-CA & $P_{i z}{ }^{-5}=p i 2$ & 26 & |RBL20-IR24 & Pi20 \\
\hline 11 & IRBLzt-T & Piz- ${ }^{t}$ & 27 & IRBLta2-Pi & Pita- $^{2}$ \\
\hline 12 & IRBLta-K1 & Pita $=$ Pi4 (t) & 28 & IRBLta2-Re & Pita- $^{2}$ \\
\hline 13 & IRBLta-CT2 & Pita $=P i 4(\mathrm{t})$ & 29 & IRBLta-CP1 & Pita $=$ Pi4 (t) \\
\hline 14 & IRBLb-B & Pib & 30 & IRBL11-Zh & $P i 11(\mathrm{t})$ \\
\hline 15 & IRBLt-K59 & Pit & 31 & IRBLz5-CA(R) & $P i z^{5}$ \\
\hline 16 & IRBLsh-S & Pish & 32 & Lijiangxintuanheigu & Susceptible \\
\hline
\end{tabular}

\section{5- Cluster analysis}

The data matrix were built depending on the blast reaction score ( 1 for resistance, 2) for moderately resistance, 3) for moderately susceptible and 4) for susceptible). Matrix was analyzed by using PAST, ver. 1.90 according to Hammer et al. (2001). The data matrix were used to calculate genetic similarity based on Euclidean's similarity coefficients, and dendrogram displaying relationships among rice entries was constructed using the Unweighted Pair Group Method with Arithmetic Mean (UPGMA).

\section{RESULTS AND DISCUSSION}

\section{Isolation of the causal organism of blast disease:}

One hundred and thirty two isolates of $P$. grisea were collected from 40 rice entries, eight commercial rice cultivars, seven promising lines, two Japanese differential varieties, and 23 monogenic lines in six rice-growing governorates in Egypt (Kafr EL-Sheikh, Gharbia, Dakahlia, Sharkia, Damietta and Beheira) during 2009 and 2010 growing seasons. Data in Table (2) show that the majority of the fungal isolates were collected from Gharbia governorate (48 isolates), followed by Kafr EL-Sheikh (36), Dakahlia (18), Sharkia (12), and Beheira (12), while the least number of isolates was recovered from Damietta governorate (6 isolates). These results are in 
agreement with the findings of Mekwatanakarn et al. (1999), El-Shafey (2002), Sehly et al. (2002), Gabr (2004), and Arafa (2012). Mackenzie (1981) and EL-Wahsh (1997) reported that the epidemics in different locations are often different, since epidemics may vary from year to year and from location to location. Arafa (2012) collected 144 blast isolates from different ricegrowing governorates in Egypt, most of them were from Kafr EL-Sheikh (69 isolates) followed by Beheira (24), Sharkia (20), Gharbia (18), and Dakahlia (11). One isolate only was obtained from Damietta governorate.

Table (2): Occurrence of blast isolates among rice-growing governorates in Egypt.

\begin{tabular}{|l|c|c|c|}
\hline \multirow{2}{*}{\multicolumn{1}{c|}{ Governorate }} & \multicolumn{2}{c|}{ Season } & \multirow{2}{*}{ Total } \\
\cline { 2 - 4 } & $\mathbf{2 0 0 9}$ & $\mathbf{2 0 1 0}$ & $\mathbf{3 6}$ \\
\hline Kafr EL-Sheikh & 21 & 15 & $\mathbf{4 8}$ \\
\hline Gharbia & 16 & 32 & $\mathbf{1 8}$ \\
\hline Dakahlia & 10 & 8 & $\mathbf{1 2}$ \\
\hline Sharkia & 8 & 4 & $\mathbf{6}$ \\
\hline Damietta & 4 & 2 & $\mathbf{1 2}$ \\
\hline Beheira & 8 & 4 & $\mathbf{1 3 2}$ \\
\hline Total & 67 & $\mathbf{6 5}$ & \\
\hline
\end{tabular}

Pathogenicity test and race identification:

One hundred and thirty two isolates were tested under artificial inoculation conditions in a greenhouse on the eight international differential varieties, 14 Egyptian rice entries and 32 monogenic lines. Data in Table (3) show that in the first season (2009), IH race group was the most common $(50.75 \%)$ followed by IC, IF, ID and IG $(22.38,10.45,7.46$, and $5.97 \%$, respectively), while IE was the least common race group (2.98\%). For the second season (2010), the most common races were also $\mathrm{IH}(44.62 \%)$ and IC (30.77\%) followed by IF (13.85\%), IG 6.15\%), and ID (4.62\%), while IE race group was absent. Generally, IH race group was the most common during the study period followed by IC and IF groups, while IG, ID, and IE were the least common race groups. IA and IB race groups were absent. Many investigators in different rice-growing countries have obtained similar results (Atkins et al., 1967; Ou, 1985 and Moldenhauer et al., 1992). Also, Chin-Chung Chin (1976) reported that susceptibility of rice plants to blast may differ from year to year even with the same variety at the same location. This phenomenon is relatively clear for susceptible varieties and suggested that it is related to the environmental conditions as well as the type and the density of the physiological blast races. Sehly et al. (2008) identified more than 200 blast isolates collected in the period from 1994 up to 2006 growing seasons in the greenhouse on the international differential varieties under artificial inoculation conditions. They reported that from 1994 to 1996, IC race group was the most common race followed by IB, ID and IG groups, while IA race group was absent. From 1997 to 2000, all groups were present; while $\mathrm{IH}$ and IG race groups were the most common. From 2001 to 2004, IG race group was the most common because it was specific on Sakha 101 rice cultivar and was responsible for its breakdown. In the last period 2005-2006, IG group 
was still the most common race followed by IB and IC race groups. On other hand, IA, IE, IH and II were absent.

Table (3): Number and percentage of common Pyricularia grisea race groups collected from different rice-growing governorates during 2009 and 2010 growing seasons.

\begin{tabular}{|c|c|c|c|c|c|c|}
\hline \multirow{3}{*}{$\begin{array}{l}\text { Race } \\
\text { group }\end{array}$} & \multicolumn{4}{|c|}{ Season } & \multirow{3}{*}{$\begin{array}{c}\text { Total } \\
\text { Number }\end{array}$} & \multirow{3}{*}{$\begin{array}{c}\text { Average } \\
\text { percentage }\end{array}$} \\
\hline & \multicolumn{2}{|c|}{2009} & \multicolumn{2}{|c|}{2010} & & \\
\hline & Number & $\%$ & Number & $\%$ & & \\
\hline IC & 15 & 22.38 & 20 & 30.77 & 35 & 26.58 \\
\hline ID & 5 & 7.46 & 3 & 4.62 & 8 & 6.04 \\
\hline IE & 2 & 2.98 & 0 & 0.00 & 2 & 1.49 \\
\hline IF & 7 & 10.45 & 9 & 13.85 & 16 & 12.15 \\
\hline IG & 4 & 5.97 & 4 & 6.15 & 8 & 6.06 \\
\hline $\mathrm{IH}$ & 34 & 50.75 & 29 & 44.62 & 63 & 47.69 \\
\hline Total & 67 & 100 & 65 & 100 & 132 & 100 \\
\hline
\end{tabular}

Pathogenicity tests revealed that GZ 9057-6-1-3-2 showed the highest resistance level against the tested isolates whereas only two isolates out of the 132 isolates tested were able to infect this rice line (98.48\% resistance) (Table 4). This was followed by Giza 178 and GZ 9523-2-1-1-1 (96.22\% for each), then Hybrid 1 and Sakha 106 (94.69\%, each), then come Sakha 103, Sakha 105, Sakha 102, Giza 177 and GZ 6296-12-1-2-1-1 (93.94\%, 93.18\%, $92.43 \%, 92.43 \%, 91.66 \%$, respectively). On other hand, the known susceptible rice cultivars, Sakha 104 and Sakha 101 were infected with 51 and 98 isolates, respectively, out of the 132 tested isolates (61.36 and $25.76 \%$ resistance, respectively). These results are in agreement with the findings of Mackill and Bonman (1986), Srinivas et al. (1998), El-Shafey (2002), Sehly et al. (2002), Gabr (2004) and Sehly et al. (2008).

Table (4): Number of infecting isolates and percentage of resistance of the tested rice entries artificially inoculated with 132 blast isolates under greenhouse conditions during 2009 and 2010 seasons.

\begin{tabular}{|l|l|c|c|c|c|}
\hline \multirow{2}{*}{ No. Entry } & \multicolumn{2}{|c|}{$\begin{array}{c}\text { Number of } \\
\text { infecting isolates }\end{array}$} & $\begin{array}{c}\text { Total Number of } \\
\text { infecting isolates }\end{array}$ & $\begin{array}{c}\text { Resistance } \\
(\%)\end{array}$ \\
\cline { 3 - 6 } & & $\mathbf{2 0 0 9}$ & $\mathbf{2 0 1 0}$ & & 92.43 \\
\hline $\mathbf{1}$ & Giza 177 & 4 & 6 & 10 & 96.22 \\
\hline $\mathbf{2}$ & Giza 178 & 5 & 0 & 5 & 25.76 \\
\hline $\mathbf{3}$ & Sakha 101 & 52 & 46 & 98 & 92.43 \\
\hline $\mathbf{4}$ & Sakha 102 & 6 & 4 & 10 & 93.94 \\
\hline $\mathbf{5}$ & Sakha 103 & 5 & 3 & 8 & 61.36 \\
\hline $\mathbf{6}$ & Sakha 104 & 21 & 30 & 51 & 93.18 \\
\hline $\mathbf{7}$ & Sakha 105 & 5 & 4 & 9 & 94.69 \\
\hline $\mathbf{8}$ & Sakha 106 & 3 & 4 & 7 & 70.45 \\
\hline $\mathbf{9}$ & Giza 182 & 22 & 17 & 39 & 94.69 \\
\hline $\mathbf{1 0}$ & Hybrid 1 & 3 & 4 & 7 & 98.48 \\
\hline $\mathbf{1 1}$ & GZ 9057-6-1-3-2 & 2 & 0 & 2 & 96.22 \\
\hline $\mathbf{1 2}$ & GZ 9523-2-1-1-1 & 1 & 4 & 5 & 32.57 \\
\hline $\mathbf{1 3}$ & GZ 9461-4-2-1-2 & 46 & 43 & 89 & 91.66 \\
\hline $\mathbf{1 4}$ & GZ 6296-12-1-2-1-1 & 8 & 3 & 11 & \\
\hline
\end{tabular}




\section{Effectiveness of blast resistance genes:}

Blast resistance genes are very important tools in rice improvement programs. Data presented in Table (5) summarize the reaction on the monogenic lines to rice blast fungus isolates. Data indicate that the frequency of resistance reactions $(R)$ of monogenic lines against the 132 isolates ranged from zero to $97.76 \%$, which were depending on the effectiveness of the present resistance gene. Piz- ${ }^{5}$ gene present in IRBLz5-CA and IRBLz5$\mathrm{CA}(\mathrm{R})$ lines was the most effective to blast fungal isolates $(97.73$ and $95.45 \%$ resistance, respectively) followed by the gene pita- ${ }^{2}$ from IRBLta2-Re (91.66\% resistance), Pi5(t) from IRBL5-M (90.15\% resistance) and then Piz, Pii, Pi9, Pita- ${ }^{2}$, and Pit from IRBLz-Fu, IRBLi-F5, IRBL9-W, IRBLta2 and IRBLt-K59, respectively $(88.64,87.88,84.09,81.82,81.06 \%$, respectively). Thus, these genes are recommended to be used by rice breeders as donors for blast resistance under Egyptian conditions. Some of these genes were also found to be highly effective against rice blast either under Egyptian conditions (Sehly et al. 2002, 2008) or under China conditions (Wang et al. 2013).

Sehly et al. (2002) evaluated 30 isolates of $P$. grisea on Japanese differential varieties to determine resistance genes against rice blast. They found that $\mathrm{Piz}^{{ }^{t}}$ in Toride 1 was moderately resistant (46.7\% resistance), while Piz in Fukunishiki, Pik in Kanto 51, Pik ${ }^{-m}$ in Tsuyake, and Pib in BL1 showed $86.7,90,93.3$, and $96.7 \%$ resistance, respectively against the 30 tested isolates. The least effective genes were Pik- $^{s}$ in Shin 2 and Pia in Aichi Asahi, which had 23.3 and $33.3 \%$ resistance, respectively. Sehly et al. (2008) reported that the effective resistance genes differed in their reaction against blast fungal isolates as Pia and Pik- ${ }^{s}$ exhibited low levels of resistance, while Pib, Pik and Pim genes showed high level of resistance during the period from 1994 to 1996. During the period from 1997 to 2000, Piz and pik genes demonstrated high levels of resistance, while Pia and Pita genes showed low levels of resistance. In the period (2001-2004), Pia and Pita- ${ }^{2}$ genes showed low levels of resistance (15 and $25 \%$, respectively). The rest of genes showed high levels of resistance (ranged from 60 to $95 \%$ ).

Wang et al. (2013) collected 200 isolates from different rice production areas in China. Out of these isolates, 44 were found to be genetically different. These isolates were inoculated onto international monogenic differentials carrying 24 major blast resistance genes i.e. Pia, Pib, Pii, Pik,

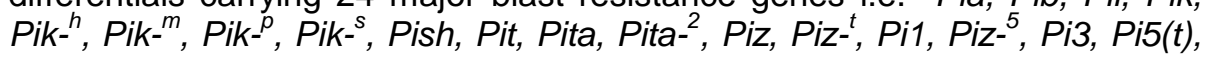
$P i 7(t)$, Pi9, Pil2(t), Pi11(t), Pi19, and Pi20 and the susceptible recurrent parent, Lijiangxintuanheigu (LTH), under greenhouse conditions. The percentage of virulent reactions of monogenic lines to the 44 isolates ranged from 8.3 to $79.2 \%$. LTH was susceptible to all 44 isolates. All 24 monogenic differential lines were resistant to at least 4 isolates of $P$. grisea, and the frequency of resistance reactions of the monogenic lines carrying Pi9, Pi19, Piz, Piz- ${ }^{5}$, Piz ${ }^{t}$, Pi12(t), Pi5(t), and Pik ${ }^{h}$ were 94.2, 84.1, 81.8, 81.8, 79.5, 72.7, 68.2, and 68.2\%, respectively. These results suggest that Pi9, Pi19, Piz, Piz- ${ }^{5}$, Piz- ${ }^{t}, P i 12(t), P i 5(t)$ and Pik- $_{-}{ }^{h}$ may be important resistant genes for preventing blast disease. 
Shabana, Y. M. et al.

Table (5): Evaluation of effective resistance genes against blast pathogen isolates and identified physiological races under greenhouse test using 132 isolates of Pyricularia. grisea

\begin{tabular}{|c|c|c|c|c|c|c|c|c|c|c|c|}
\hline \multirow[t]{2}{*}{$\begin{array}{l}\text { Monogenic } \\
\text { line }\end{array}$} & \multirow[t]{2}{*}{$\begin{array}{c}\text { Target } \\
\text { gene }\end{array}$} & \multicolumn{6}{|c|}{ Common race group } & \multicolumn{2}{|c|}{$\begin{array}{c}\text { No. of } \\
\text { infecting } \\
\text { isolates per } \\
\text { growing } \\
\text { season }\end{array}$} & \multirow[t]{2}{*}{$\begin{array}{c}\text { Total } \\
\text { No. of } \\
\text { infecting } \\
\text { isolates }\end{array}$} & \multirow[t]{2}{*}{$\begin{array}{c}\text { Gene } \\
\text { infectivity } \\
(\%)\end{array}$} \\
\hline & & IC & ID & IE & IF & IG & IH & 2009 & 2010 & & \\
\hline IRBLa-A & Pia & 35 & 8 & 2 & 16 & 8 & 63 & 67 & 65 & 132 & 0.00 \\
\hline IRBLa-C & Pia & 35 & 8 & 2 & 16 & 8 & 63 & 67 & 65 & 132 & 0.00 \\
\hline IRBLi-F5 & $P i i$ & 6 & - & - & 5 & 3 & 2 & 5 & 11 & 16 & 87.88 \\
\hline IRBLks-F5 & Pik-s & 35 & 8 & 2 & 14 & 8 & 61 & 64 & 61 & 125 & 5.31 \\
\hline IRBLks-S & Pik-s & 31 & 6 & 2 & 16 & 8 & 55 & 58 & 60 & 118 & 10.61 \\
\hline IRBLk-ka & Pik & 26 & 1 & - & 11 & 3 & 14 & 22 & 33 & 55 & 58.33 \\
\hline IRBLkp-K60 & Pik- $^{p}$ & 25 & 2 & - & 12 & 2 & 14 & 25 & 30 & 55 & 58.33 \\
\hline IRBLkh-K3 & Pik- ${ }^{h}$ & 27 & 1 & - & 10 & 3 & 12 & 20 & 33 & 53 & 59.85 \\
\hline IRBLz-Fu & Piz & 6 & 1 & - & 3 & 4 & 1 & 7 & 8 & 15 & 88.64 \\
\hline IRBLz5-CA & Piz- ${ }^{5}$ & - & - & - & 2 & - & 1 & 3 & 0 & 3 & 97.73 \\
\hline IRBLzt-T & Piz- ${ }^{t}$ & 26 & 8 & 2 & 10 & 8 & 54 & 52 & 56 & 108 & 18.18 \\
\hline IRBLta-K1 & Pita & 21 & 8 & 1 & 10 & 5 & 42 & 44 & 43 & 87 & 34.09 \\
\hline IRBLta-CT2 & Pita & 28 & 8 & 2 & 11 & 8 & 52 & 42 & 55 & 97 & 26.52 \\
\hline IRBLb-B & Pib & 21 & 8 & 2 & 10 & 8 & 58 & 53 & 54 & 107 & 18.94 \\
\hline IRBLt-K59 & Pit & 6 & 3 & - & 2 & 2 & 12 & 14 & 11 & 25 & 81.06 \\
\hline IRBLsh-S & Pish & 25 & 5 & 1 & 14 & 8 & 39 & 42 & 44 & 86 & 34.85 \\
\hline IRBLsh-B & Pish & 11 & 4 & - & 7 & 6 & 15 & 23 & 20 & 43 & 67.43 \\
\hline IRBL1-CL & Pi1 & 27 & 2 & - & 10 & 3 & 8 & 21 & 29 & 50 & 62.12 \\
\hline IRBL3-CP4 & Pi3 & 15 & 5 & - & 11 & 6 & 29 & 26 & 40 & 66 & 50.00 \\
\hline IRBL5-M & Pi5 (t) & 11 & - & - & 1 & 1 & - & 5 & 8 & 13 & 90.15 \\
\hline IRBL7-M & $P i 7(t)$ & 26 & 1 & - & 11 & 2 & 4 & 17 & 27 & 44 & 66.66 \\
\hline IRBL9-W & Pi9 & 6 & 3 & - & 1 & 2 & 9 & 12 & 9 & 21 & 84.09 \\
\hline IRBL12-M & Pi12 (t) & 22 & 5 & 1 & 13 & 8 & 37 & 43 & 43 & 86 & 34.58 \\
\hline IRBL19-A & Pi19 & 35 & 8 & 2 & 16 & 8 & 56 & 62 & 51 & 113 & 14.39 \\
\hline IRBLkm-Ts & Pik- $^{m}$ & 25 & - & - & 13 & 1 & 5 & 19 & 25 & 44 & 66.66 \\
\hline IRBL20-IR24 & Pi20 & 32 & 8 & 2 & 16 & 8 & 51 & 58 & 59 & 117 & 11.36 \\
\hline IRBLta2-Pi & Pita- $^{2}$ & 6 & 3 & - & 4 & 1 & 9 & 11 & 13 & 24 & 81.82 \\
\hline IRBLta2-Re & Pita- $^{2}$ & 2 & 2 & - & 2 & 1 & 4 & 7 & 4 & 11 & 91.66 \\
\hline IRBLta-CP1 & Pita & 31 & 8 & 2 & 15 & 8 & 56 & 54 & 61 & 115 & 12.88 \\
\hline IRBL11-Zh & $P i 11(t)$ & 28 & 8 & 1 & 14 & 8 & 55 & 56 & 54 & 110 & 16.66 \\
\hline $\begin{array}{l}\text { RBLz5-CA } \\
\text { (R) }\end{array}$ & $\mathrm{Piz}^{5}$ & 2 & 1 & - & 1 & 1 & 1 & 5 & 1 & 6 & 95.45 \\
\hline LTH & - & 35 & 8 & 2 & 16 & 8 & 63 & 67 & 65 & 132 & 0.00 \\
\hline
\end{tabular}

On contrary, in our study Pia gene from IRBLa-A and IRBLa-C lines was found to be the least effective gene against blast fungal isolates with zero\% resistance.

The dendrogram in Fig. (1) and Table (5) explains the genetic relatedness among the tested rice genotypes depending on their blast reaction scores. The monogenic lines were divided into two main groups (clusters "A" and "B"). The cluster "A" included the monogenic lines that their resistance percentage ranged from 50 to $97.73 \%$, while cluster "B" included the monogenic lines that exhibited resistance percentage ranged from zero to $34.85 \%$. Monogenic lines with resistance percentage ranged from 58 to 
$66.66 \%$ were grouped into the sub cluster "A2". Higher resistant genes on genotypes of resistance percentage ranged from 81.82 to $97.73 \%$ were grouped in one sub cluster "A1".

Fig. (1) Cluster analysis for 32 monogenic lines.

\section{Distribution of physiological races:}

The pathogenicity tests using the international differential varieties indicated that 6 race groups were identified i.e., IC, ID, IE, IF, IG and IH (Table 6). These race groups included 20 races (one from each of IC-1, IC-9, IC-11, IC-15, IC-21, IC-29; two from each of IC-3, IC-17; twelve from IC-19; five from IC-25; four from each of IC-27, IC-31; one from each of ID-13, ID-1; six from ID-15; two from IE-5; six from IF-1; ten from IF-3; eight from IG-1; and 63 from $\mathrm{IH}-1$ ). IC race group was the most common race in Kafr ElSheikh governorate with incidence of $9.09 \%$, while IH was the most common in Gharbia, Dakahlia, Behrira, Sharkia and Damietta with incidence of 17.43, $7.56,6.82,6.06$, and $1.52 \%$ respectively. IA and IB race groups were absent during this study. Data in Table (6) show the distribution of physiological races over the rice-growing governorates, indicating that the highest incidence of races were present in Gharbia and Kafr El-Sheikh governorates (36.53 and $27.27 \%$, respectively). Therefore, these governorates are considered a hot spot for rice blast disease, which is true. Dakahlia, Behrira and Sharkia had moderate presence of blast races (13.62, 9.10 and $9.10 \%$, respectively). Damietta governorate had the lowest incidence of races 
(4.56\%). These results are in agreement with the findings of Sehly et al. (2002) and Gabr (2004) who reported that the distribution of physiological races of blast pathogen differed based on location (rice-growing governorates). The common physiological races (pathotypes) present in Egypt suggest the existence of a wide genetic variability of blast races.

Table (6): Distribution of physiological races of Pyricularia grisea over rice-growing governorates in 2009 and 2010 growing seasons.

\begin{tabular}{|l|c|c|c|c|c|c|c|}
\hline \multirow{2}{*}{ Race } & \multicolumn{7}{|c|}{ Distribution (\%) } \\
\cline { 2 - 7 } & IC & ID & IE & IF & IG & IH & \\
\hline Kafrelsheikh & 9.09 & 2.27 & 0.00 & 4.55 & 3.03 & 8.33 & 27.27 \\
\hline Gharbia & 9.84 & 3.03 & 0.00 & 3.78 & 2.27 & 17.43 & 36.35 \\
\hline Dakahlia & 3.03 & 0.00 & 0.76 & 2.27 & 0.00 & 7.56 & 13.62 \\
\hline Damietta & 1.52 & 0.00 & 0.76 & 0.76 & 0.00 & 1.52 & 4.56 \\
\hline Sharkia & 1.52 & 0.76 & 0.00 & 0.00 & 0.76 & 6.06 & 9.10 \\
\hline Beheira & 1.52 & 0.00 & 0.00 & 0.76 & 0.00 & 6.82 & 9.10 \\
\hline Total & 26.52 & 6.06 & 1.52 & 12.12 & 6.06 & 47.72 & 100.00 \\
\hline
\end{tabular}

${ }^{\text {a }}$ Distribution (\%) = number of each physiological race

total number of races (132) $X 100$

\section{REFERENCES}

Abd-El-Hak, T. M. (1981). Rice disease and assessment of their impact in Egypt. Proc. 1st National Rice Inst. Conf., 21(25):114-121.

Arafa, R. A. M. (2012). Studies on Identification of the Physiological Races of the Rice Blast Fungus by Traditional and Genetic Methods. M.Sc. thesis, Plant Pathol. Dept., Fac. Agric., Kafrelsheikh Univ.

Atkins, J.G.; A. L. Robert; C. R. Adair; K. Goto; T. Kozako; R.Yanagida; Y. Yamada and S. Matsumoto (1967). An international set of rice varieties for differentiating races of Pyricularia oryzae. Phytopathology, 57: 298301.

Bastiaans, L. (1993). Effects of leaf blast on photosynthesis of rice. 1-leaf photosynthesis. Netherlands Journal of Plant Pathology, 99: 197-203.

Chin-Chung, C. (1976). Levels of host resistance in relation to the incidence of rice blast. Department of plant pathol. Taiwan Agric. Research Institute. Wu-Feng, Taichung, Taiwan, 431.

Couch, B.C. and L.M. Kohn (2002). A multi locus gene genealogy concordant with host preference indicates segregation of a new species, Magnaporthe oryzae, from M. grisea. Mycologia, 94(4): 683-693.

Eizenga, G.C.; H.A. Agrama; F.N. Lee; W. Yan and F.N. Lee (2006). Identifying novel resistance genes in newly introduced blast resistant rice germplasm. Crop Sci. 46: 1870-1878.

El-Kazzaz, M. K. (1973). Studies on Diseases Affecting Rice Crop in Egypt. Ph.D. Thesis, Fac. Agric., Alexandria Univ.

El-Shafey, R. A. (2002). Studies on Pyricularia oryzae the Causal Organism of Rice Blast Disease and Its Control. M.Sc. Thesis, Fac. Agric. Monufeia Univ. 
EL-Wahsh, S. M. (1997). Studies on Both Brown Spot and Blast Diseases of Rice in Egypt. Ph.D. Dissertation, Fac. Agric., Tanta Univ.

Flor, H.H. (1971). Current status of gene-for-gene concept. Adv. Genet. 8: $29-54$.

Fukuta, Y.; M.J. Telebanco-Yanoria; T. Imbe; H. Tsunematsu; H. Kato; T. Ban; L.A. Ebron; N. Hayashi; I. Ando and G.S. Khush (2004). Monogenic lines as an international standard differential set for blast resistance in rice (Oryza sativa L.). Rice Genet. Newsl. 21: 70-72.

Gabr, W. E. (2004). Studies on Rice Blast Disease in Egypt. M.Sc. Thesis, Fac. Agric. Kafr El-Sheikh, Tanta Univ.

Hammer, Q.; Harper, D.A.T. and P.D. Ryan, (2001). PAST: Paleontological statistics software package for education and data analysis. Palaeontologia Electronica. 4(1): 9pp. http://palaeoelectronica.org/2001_1/past/issue1_01.htm.

IRRI (1996). International Rice Research Institute. Standard Evaluation System for Rice, $3^{\text {rd }}$ ed. IRRI, Los Banos, Philippines.

Koizumi, S. (2007). Durability of resistance to rice blast disease. Pages 1-10 in: Fukuta, Y., C.M. Vera-Cruz and N. Kobayashi (eds.). A Differential System for Blast Resistance for Stable Rice Production Environment, Tsukuba, Japan, JIRCAS Working Report No. 53.

Mackenzie, D. R. (1981). Breeding for disease resistance in cereals. Pages 63-69 in: Proc. of the $18^{\text {th }}$ Annual Meeting, Canadian Pest Management Society at St. Catharines, Ontario, Agu.

Mackill, A. O. and J. M. Bonman (1986). New hosts of Pyricularia oryzae. Plant Disease, 70: 125-127.

Mackill, D.J.; J. M. Bonman; H.S. Suh and R. Srilingam (1985). Genes for resistant to Philippine isolates of the rice blast pathogen. Rice Genet. News. 2:80-81.70: 125-127.

Mekwatanakarn, P; W. Kositratana; T. Phomraksa and R. S. Zeigler (1999). Sexually ferial Magnaporthe grisea rice pathogens in Thailand. Plant Disease 83:939-943.

Moldenhauer, K. A. K.; A. O. Bastawisi and F. N. Lee (1992). Inheritance of resistance in rice to race IB-49 and IC-17 of Pyricularia grisea rice blast. Crop Science 32: 584- 588.

Ou, S. H. (1985). Rice Diseases, 2nd ed. Commonwealth Mycological Institute Kew, UK, pp 380.

Sehly, M. R.; S. M. EL-Wahsh; M. M. EL-Malky ;E. A. S. Badr; R. A. S. ELShafey and I. R. Aidy (2008). Evaluation of certain Egyptian rice cultivars to blast disease incidence during fourteen years. Egyptian Journal of Agriculture Science, Mansura Univ., 33(4): 2643-2657.

Sehly, M. R.; Z. H. Osman; E. A.Salem; I. R. Aidy and A. E. Draz (1993). Multilocation test for rice blast reaction in relation to race distribution. Egypt. J. Appl. Sci., 8(2): 136-152.

Sehly, M.R. ; Z. H. Osman and E.A. Salem (2002). Rice Diseases. In : Rice in Egypt (ed. Theresa A. Castillo). Rice Research and Training Center, Sakha, Kafr El-Sheikh, Egypt. pp. 198-247. 
Silue, D.; J.L. Notteghem and D. Tharreau (1992). Evidence for a geneforgene relationship in the Oryza sativa-Magnaporthe grisea pathosystem. Phytopathology 82: 577-580.

Srinivas, P. M.; K. Sangit and M. S. Lakhmiprasada (1998). Weed hosts for rice blast fungus in Meghalaya, India. Oryza 35(4):384-385.

Tsunematsu, H.; M.J.T. Yanoria; L.A. Ebron; N. Hayashi; I. Ando, H. Kato; T. Imbe and G.S. Khush (2000). Development of monogenic lines for rice blast resistance. Breed. Sci. 50:229-234.

Wang, J.C. ; Y. Jiab; J.W. Wen ; W.P. Liu ; X.M. Liu ; L. Li ; Z.Y. Jiang ; J.H. Zhang ; X.L. Guo and J.P. Ren (2013). Identification of rice blast resistance genes using international monogenic differentials. Crop Protection 45:109-116.

Zeigler, R.S.; J. Thome; J. Nelson; M. Levy and F. Correa (1994). Linking blast population to resistance breeding: A proposed strategy for durable resistance. Pages 267-292 in: Zeigler, R.S., S. Leong and P.S. Teng (eds.). Rice Blast Disease. CAB International, Wallingford, UK.

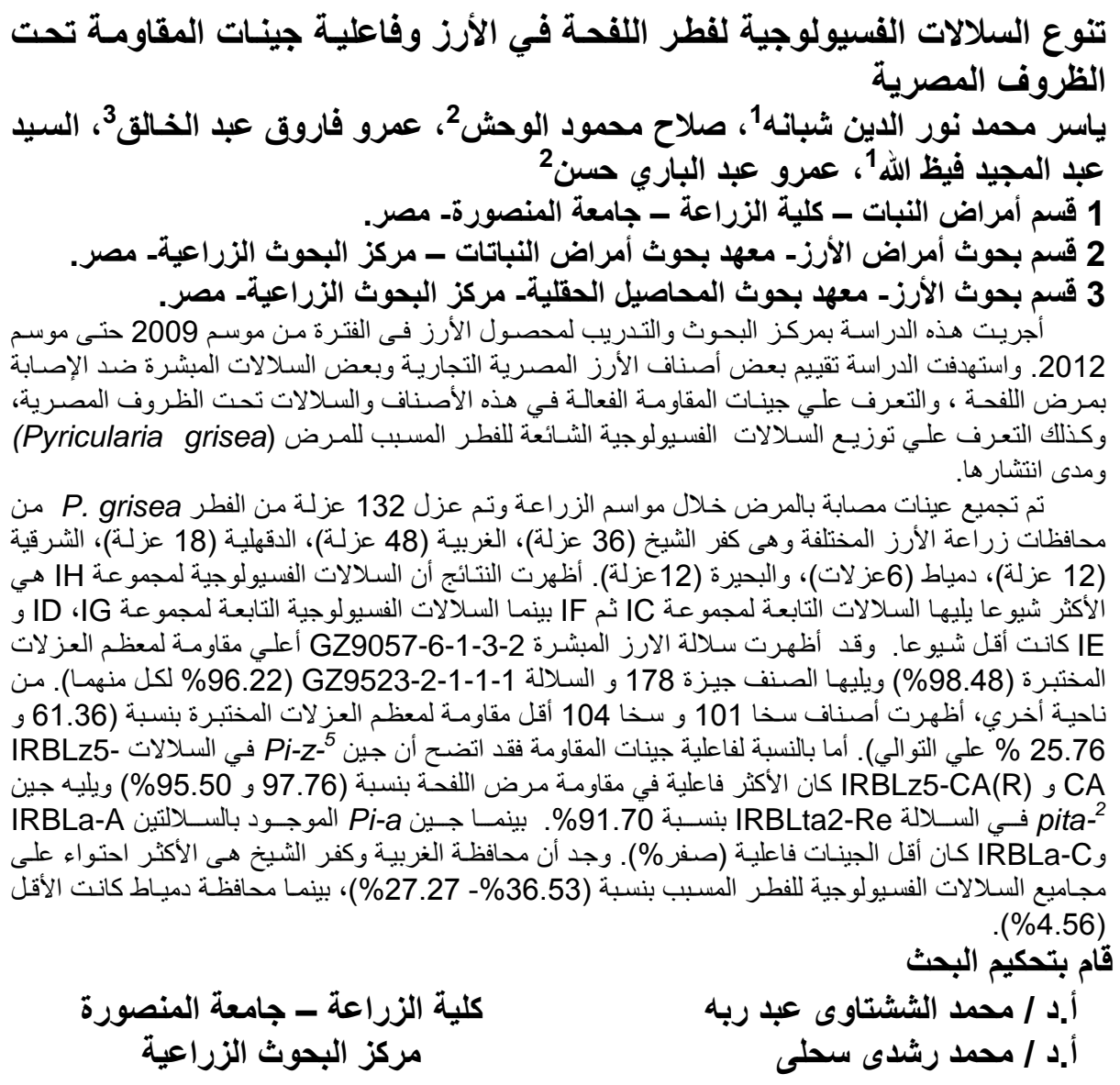

